\title{
Machinima interventions: innovative approaches to immersive virtual world curriculum integration
}

\author{
Andrew John Middleton* and Richard Mather \\ Learning and Teaching Institute, Sheffield Hallam University, Sheffield, UK
}

(Received 1 April 2008; final version received 8 September 2008)

\begin{abstract}
The educational value of Immersive Virtual Worlds (IVWs) seems to be in their social immersive qualities and as an accessible simulation technology. In contrast to these synchronous applications this paper discusses the use of educational machinima developed in IVW virtual film sets. It also introduces the concept of media intervention, proposing that digital media works best when simply developed for deployment within a blended curriculum to inform learning activity, and where the media are specifically designed to set challenges, seed ideas, or illustrate problems. Machinima, digital films created in IVWs, or digital games offer a rich mechanism for delivering such interventions. Scenes are storyboarded, constructed, shot and edited using techniques similar to professional film production, drawing upon a cast of virtual world avatars controlled through a human-computer interface, rather than showing real-life actors. The approach enables academics or students to make films using screen capture software and desktop editing tools. In student-generated production models the learning value may be found in the production process itself. This paper discusses six case studies and several themes from research on ideas for educational machinima including: access to production; creativity in teaching and learning; media intervention methodology; production models; reusability; visualisation and simulation.
\end{abstract}

Keywords: digital media; immersive virtual worlds; machinima; simulation; media interventions

\section{Introduction}

Immersive Virtual Worlds (IVWs) have attracted the attention of educators over recent years, especially since the release of Second Life, one of the most popular of several internet-based virtual worlds (Littleton and Bayne 2008). The value and attraction of IVWs to education is in the ease they promise the general educational user for creating simulations in an immersive, abstracted space, offering students the opportunity to synchronously encounter authentic experiences involving other people, objects and environments. Interest in simulation is growing amongst educators who believe experiential learning has a role in engaging students (Aldrich 2005; Dickey 2005; de Freitas 2006) and that the visualisation of ideas accommodates a range of learning styles and teaching strategies (Burbules 1999).

The opportunities offered by IVWs are counterbalanced by barriers to access including: lack of academic technical literacy and commitment to learn new technology; academic inertia; the threat to academic freedom and autonomy; usability; reliability; affordability;

\footnotetext{
*Corresponding author. Email: a.j.middleton@shu.ac.uk
} 
compatibility; and support requirements. Will academics risk hours of their time in developing teaching on the chance that the technology enhances the curriculum (Roberts 2008; Collis and Moonen 2002; Shephard 2003)?

The authors have previously explored the potential of digital media in the context of student-centred pedagogies and this has resulted in various 'media intervention' curriculum design methodologies, including audio feedback, educational podcasting models, studentgenerated video and digital storytelling.

In this development media intervention techniques are connected with IVWs through the process of making digital video learning objects on IVW virtual film sets. The collaborative design of films made in IVWs, known as machinima, proved to be a rewarding exercise, leading to the generation of six storyboards and a better understanding of the benefits, challenges and potential of educational machinima.

This paper presents six short case studies of design conversations with academics, representing a range of disciplines, towards finding more widespread applications for IVWs in engaging learners in higher education curricula.

\section{Background}

Lombardi (2007) notes that developing authentic learning activities enriches learning and that such activities need not be limited to real-life locations and practice, as authenticity can also be found through the design of blended learning environments, which Yoon and Lim $(2007,475)$ describe as "a purposeful mix of delivery media". The concept of media intervention (Bradley, Middleton, and Nunnington 2006) proposes such a mix. Media intervention methodology also encourages wider consideration of locally developed digital media in higher education by reducing the barriers created by technical processes that are perceived to be overly complicated (Collis and Moonen 2002). Instead, it encourages academics to view digital media objects as simple resources deployed with the intention of promoting active, student-centred learning designed to set challenges, seed ideas, or illustrate problems so as to quickly engage and affect the learner. Media interventions may be rapidly deployed in response to emerging needs, or as student responses to emerging knowledge. Their successful deployment, however, is dependent upon ease of production and integration.

Media intervention can encompass the re-use of existing media objects as well as the production of new objects by staff, students, technicians, or external suppliers. The value of the media is found in its currency, authenticity, specificity, repeatability and occasionally in its constructionist value (Papert 1986; Kafai 1996), rather than in its production value. The asynchronous nature of these media objects heightens their potential learning impact by letting the student user determine their timely application (Middleton 2008). This results in digital media moving away from transmission and towards conversation (Laurillard 2002). In the age of user-generated grass roots video and podcasting (Horizon Project 2008), digital media become viable channels in extending the virtual learning environment and, through media intervention, promote change in the teacher's role towards that of guide, seeder of ideas, and motivator.

IVWs, such as Second Life, allow the user to create props and scenery and, if necessary, program them with behaviours. Such objects can be small (e.g. buttons on a mobile phone) or huge (e.g. office blocks).

Machinima have been described as "animated filmmaking within a real-time virtual 3D environment" delivered as digital video (Daly-Swanson 2007). Machinima production first emerged in 2001 in the gaming community and has since been featured in film festivals and 
other public presentations. Films are made by orchestrating and recording avatars and objects in real-time. The avatars, animated 3D representations of people or other beings, are manipulated as virtual puppets (Lowood 2006) by real people through computer interfaces. A film with a large cast may therefore require several puppeteers (Nitsche 2005).

Machinima recording involves screen-capture, with the resultant video footage edited using desktop software. Sound-tracks and effects can also be applied at this stage. Finally the films are exported to a digital video file. Machinima production follows the same procedures, and uses similar techniques, as real-world filmmaking: scenes are storyboarded, shot, edited and processed. This can be brief, requiring just one or two people, or extensive. Films can be sophisticated productions or, at their simplest, can be rudimentary CCTV-type recordings of whatever happened whilst 'the camera' was switched on (Call 2005).

IVWs bring the film set and the cast to the producer and this can make it attractive to educationalists where a lack of access to budgets, people, locations and time contribute to the inaccessibility of educational video production (Bardzell et al. 2006). For example, Second Life is a widely accessible online environment that supports multi-user engagement. In addition it can be used for free and provides tools to enable the user construction of interactive objects. Users can also import images to speed up set development. Compared to real-world filmmaking, machinima production is cost-effective, timeefficient and offers producers a large amount of creative control (Academy of Machinima Arts \& Sciences website 2005). Machinima and simulation, used together, therefore offer functionality to academic innovators that until now has been out of reach and so creatively unexplored.

Recent interest in Second Life from educators (Kirriemuir 2007) suggests that although IVWs promise many opportunities for synchronous interaction and learning, machinima production results in objects that have an asynchronous value.

Machinima can be produced using various 3D environments. However, Bardzell et al. (2006), in an evaluation of machinima platforms, conclude that Second Life (as an example of their 'hybrid games' category) offers a range of functionality that makes it better suited than either 'pure games' or 'pure machinima' platforms for machinima development. Games such as The Sims and The Movies do not offer the freedom to customise sets, props and camera angles that can be found in Second Life, and machinima platforms such as Moviestorm (http://www.moviestorm.co.uk), Virtual Stage (http://www.dakinewave.com/ virtualstage/index.htm) and Machinimation (http://www.fountainheadent.com/n.x/fe/ Home/Productions/Machinimation) are promising, though complex or too limited to support the diversity of educational ideas as discussed here.

As IVWs become more familiar to students, they may become widely accepted as creative production spaces for student group work. Filmmaking provides a useful framework in which to set a collaborative assignment and, as a learning space, may encourage participants to apply a range of interpersonal and organisational skills. Its narrative nature connects to emerging interest in educational digital storytelling (Jenkins and Lonsdale 2007) and other techniques that promote the student voice.

Carr (2007) describes how the US Navy is capturing simulation activity for review, finding it to be safe and depersonalised and produced "at a fraction of traditional audio/video production costs". The Second Health project (Second Health, website and online machinima at http://secondhealth.wordpress.com) has created a Second Life presence and a series of machinima, allowing service users to experience proposals for London healthcare provision. Machinima production is also used in schools to encourage student autonomy and engagement (Czarnecki 2007). Elsewhere large groups are offered diverse experience and 
skill development through the creation of sets, costumes, stunts and special effects that, otherwise, would not be possible (Joseph 2007).

\section{Methodology}

The aim of this ongoing work is to discover whether machinima produced in IVWs can be used to engage learners across the higher education curriculum. A concept of machinima media intervention has been developed and used to underpin this research.

Outline information about IVWs, machinima and media interventions was included in an e-mail invitation to selected academics who were also informed that they had been specifically chosen to contribute on the basis that they had demonstrated an interest in academic innovation in previous work. This enabled the current research to acknowledge and build upon prior success strategies employed by those taking part. Together they represented a wide range of disciplines.

Semi-structured interviews with academic participants were carried out to create case studies around a collaborative task of completing a design specification and storyboard for the production of machinima. The interview method may be more usefully described, therefore, as design conversations. This approach was devised to engender a creative attitude amongst participants and to encourage consideration of the pedagogic opportunities offered by media interventions. It was also intended to dissuade participants from dwelling on the technical barriers, real or imagined.

Six academics agreed to participate. Some had heard of Second Life, but none had used it or were familiar with the machinima or media intervention concepts. The invitation explained that part of the design sessions would include an induction to Second Life, IVWs in general, machinima and the media intervention concept.

The first 20 minutes in each conversation were used to introduce the various concepts and technologies. This was followed by a demonstration of between five and 10 short machinima (Appendix 1), each selected to illustrate facets that could be used to inform the design process. First, a short machinima with a strong narrative and high cinematic value was shown. This was followed by short YouTube (http://www.youtube.com) video clips that described Second Life, methods of constructing objects, collaborative activity and educational applications for IVWs and machinima. Using YouTube clips to introduce concepts was a useful technique and served to demonstrate how media can generate discussion.

Following familiarisation, participants were asked to design a machinima in collaboration with the authors. Informed and inspired by the induction, design conversations focused on the completion of a design specification proforma. Discussion of wider issues was also encouraged. Each conversation was limited to two hours, which provided a useful design constraint. The academic participant was joined by both authors: one who completed the specification, clarifying the design idea through its documentation; the other responsible for encouraging creativity, reviewing understanding of the related concepts used to inform the design, and ensuring that the conversation covered the intended scope of the research. Data were captured on the proforma and in audio recordings of the conversations. Six common themes emerged from analysis of the full transcripts, as discussed in the results section.

\section{Case studies}

\section{Results}

Analysis of transcripts of the design conversations resulted in the identification of six themes. 
Table 1. Case study descriptions.

\section{Psychology}

\begin{tabular}{ll}
\hline Module: & $\begin{array}{l}\text { Forensic Psychology } \\
\text { Participant: }\end{array}$ \\
$\begin{array}{l}\text { Confident user of ICT; enthusiastic about trying new technologies if the } \\
\text { pedagogical benefits are clear; some knowledge of IVWs. }\end{array}$ \\
Machinima idea: & $\begin{array}{r}\text { A car crash involving two vehicles, seen by two witnesses, one of whom has } \\
\text { an obstructed view. The crash is shown from various angles, and may } \\
\text { include details and commentaries. More detail is released to students over } \\
\text { time, in increasingly longer video clips, as the module progresses. }\end{array}$ \\
Application: & $\begin{array}{r}\text { Used in lecture to stimulate thinking and discussion, and to challenge student } \\
\text { perceptions. Students could be invited to manipulate the scene themselves. }\end{array}$ \\
Intended impact: & $\begin{array}{r}\text { Perceptions challenged; familiarity with perception theories; theories of } \\
\text { bystander intervention and eyewitness testimony. }\end{array}$ \\
Reusability: & $\begin{array}{r}\text { Other subject areas (e.g. Criminology, Sociology, Transport Design, Urban } \\
\text { Planning, Physics, Engineering). }\end{array}$ \\
Other ideas: & $\begin{array}{r}\text { Global real estate and architectural projects that cover a range of global } \\
\text { perspectives, with different people in different locations. }\end{array}$ \\
\hline
\end{tabular}

\section{Sport}

$\begin{array}{ll}\begin{array}{l}\text { Module: } \\ \text { Participant: }\end{array} & \begin{array}{l}\text { Gymnastics, Exercise Prescription } \\ \text { Confident user of ICT; enthusiastic about trying new technologies if the } \\ \text { pedagogical benefits are clear; has innovated with digital media; some } \\ \text { knowledge of IVWs. }\end{array} \\ \text { Machinima idea: } & \begin{array}{r}\text { Students populate a pre-designed virtual gymnasium with pre-designed } \\ \text { equipment recording their layouts as short video clips; commentary to } \\ \text { capture their reasoning. }\end{array} \\ \text { Application: } & \begin{array}{l}\text { As a formative assessment. } \\ \text { Intended impact: }\end{array} \\ \begin{array}{l}\text { Knowledge of how to set up an exercise environment; exploring an environment } \\ \text { in which they can experiment. } \\ \text { Reusability: }\end{array} & \begin{array}{l}\text { Student-submitted machinima added to a library of examples for future use. The } \\ \text { fitness space and equipment could be used in a number of other ways. }\end{array} \\ \text { Other ideas: } & \begin{array}{l}\text { Setting up a biomechanical experiment; instructional videos of how to use } \\ \text { equipment with voiceovers in different languages; setting up of fitness } \\ \text { activities for specific scenarios, e.g. training elite athletes or rehabilitation } \\ \text { from an injury. Simulating scenarios which might be ethically problematic, } \\ \text { e.g. interviewing children about obesity; rehabilitation. }\end{array}\end{array}$

3. Business and Technology

\begin{tabular}{ll}
\hline Module: & $\begin{array}{l}\text { Computing Foundation Degree } \\
\text { Participant: }\end{array}$ \\
$\begin{array}{l}\text { Confident user of ICT; enthusiastic about trying new technologies if the } \\
\text { pedagogical benefits are clear; some awareness of IVWs; innovates in inter- } \\
\text { disciplinary teaching and blended learning. }\end{array}$ \\
Machinima idea: & $\begin{array}{c}\text { An avatar, assuming the role of Managing Director of a major company, gives } \\
\text { a briefing for a group of students. }\end{array}$ \\
Application: & $\begin{array}{c}\text { Used in a real-world group assignment briefing supporting an educational } \\
\text { simulation. The machinima clip is used as a surrogate Managing Director. }\end{array}$ \\
Intended impact: & Professional development. \\
\hline
\end{tabular}


Table 1. (Continued).

\begin{tabular}{ll}
\hline Reusability: & $\begin{array}{l}\text { Re-use by replacing avatar voiceovers in the machinima; across disciplines } \\
\text { where insight to boardroom activity is useful. }\end{array}$ \\
Other ideas: & $\begin{array}{l}\text { Creation of built environments (e.g. an office location), which students have to } \\
\text { fit out, recording their solutions as machinima. Alternatively the students } \\
\text { could be given existing video clips of the space to which they have to add } \\
\text { captions, text descriptions, or voiceover. }\end{array}$
\end{tabular}

4. Criminology

\begin{tabular}{ll}
\hline $\begin{array}{l}\text { Module: } \\
\text { Participant: }\end{array}$ & $\begin{array}{l}\text { Criminal Justice Systems } \\
\text { Enthusiastic about blended learning; basic ICT skills and a little intimidated by } \\
\text { technology and the time it takes to learn new skills. }\end{array}$ \\
$\begin{array}{l}\text { Machinima idea: } \\
\text { Application: }\end{array}$ & $\begin{array}{l}\text { Depiction of a crime, a subsequent arrest, and resultant police interview. } \\
\text { A stand-alone video clip describing a common crime and the processes of the } \\
\text { criminal justice system (CJS). Eventually replacing lectures by encouraging } \\
\text { student engagement in other ways. }\end{array}$ \\
$\begin{array}{l}\text { Knowledge of the CJS; ability to discuss an offender's journey through the CJS } \\
\text { in relation to the various agencies; awareness of the strengths and limitations } \\
\text { of the CJS. }\end{array}$ \\
$\begin{array}{l}\text { Re-use at different levels of study. } \\
\text { Other ideas: }\end{array}$ & A series representing the whole criminal justice system.
\end{tabular}

\section{Teacher Education}

\begin{tabular}{|c|c|}
\hline Module: & PGCE Learning and Skills Sector \\
\hline Participant: & $\begin{array}{l}\text { Experienced and confident user of ICT; enthusiastic about innovation in } \\
\text { teaching and learning; some knowledge of virtual worlds including one used } \\
\text { for language learning. }\end{array}$ \\
\hline Machinima idea: & $\begin{array}{l}\text { Classroom behaviour management - short films of classroom scenarios, } \\
\text { including disruptive students and how to deal with them. A teacher begins a } \\
\text { lesson by introducing a task. As the students begin to engage, one of them } \\
\text { becomes unruly. The machinima would use recordings from real } \\
\text { classrooms. }\end{array}$ \\
\hline Application: & $\begin{array}{l}\text { In class to promote discussion; as a reference for education students who are } \\
\text { out on teaching practice. }\end{array}$ \\
\hline Intended impact: & Increased confidence and skills in classroom management. \\
\hline Reusability: & Re-use of locations for all levels of teacher education. \\
\hline Other ideas: & Education policy; modelling of classroom-based research activity. \\
\hline
\end{tabular}

6. Microbiology

\begin{tabular}{|c|c|}
\hline Module: & Pathogenesis of infectious disease \\
\hline Participant: & $\begin{array}{l}\text { Experienced in the use of ICT and blended learning; enthusiastic about } \\
\text { teaching with a wide range of media; some knowledge of virtual worlds. }\end{array}$ \\
\hline Machinima idea: & $\begin{array}{l}\text { Interaction between cells - the 'battle' between bacteria with virulence factors } \\
\text { and the human defence system. This is usually very difficult to visualise. }\end{array}$ \\
\hline Application: & Machinima available in the VLE or used in taught sessions. \\
\hline Intended impact: & $\begin{array}{l}\text { Deeper understanding of the interaction between bacteria and the human } \\
\text { defence system. }\end{array}$ \\
\hline
\end{tabular}


Table 1. (Continued).
Reusability:
The film could be used for other subject areas, e.g. nursing where there is a need for more basic understanding of microbiology. Some of the modelled components (bacteria, cells, etc) could be re-used in other films.

Other ideas:

None. Participant was not keen on the idea of virtual lab machinima.

\section{Access to the means of production and other benefits of machinima production}

When participants were asked why machinima may be more useful than other approaches, several explained how developing their ideas using real-life footage would require high budgets and access to a crew and locations. In the Business scenario the academic explained that a new office construction could be a fantastic learning resource, but the building's state and site personnel change continuously. This project could become cost-effective by developing an IVW simulation and capturing interactions as machinima. Lack of access to physical locations contributed to ruling out video as an option in five cases and in the sixth, Psychology, filming a car crash was not feasible. Access to professional production facilities is also problematic for academics and students alike, though many universities are developing student-generated media project-based learning initiatives (Bramhall, Radley, and Metcalf 2008; Hung, Keppell, and Jong 2004).

The Sport academic explained that, "Time is pretty expensive". This concern was shared by others who agreed that finding time to carry out work with traditional media is problematic and that productions involving other people introduce dependencies and inflexibilities. Virtual world filming typically requires less crew and cast and can fit alongside other commitments more easily. Time pressures around the use of physical space and equipment can distort the quality of learning and its assessment, according to the Sport tutor who described how students are expected to lay out the gym in a specific time slot for an assessment on decision-making about spatial solutions. If they make a mistake they have little opportunity to rectify it. In an IVW students can prepare in their own time and produce commented machinima of their decision-making process. It becomes easier for them to try different configurations of equipment, identify hazards and optimise their solutions. The real-world activity required unnecessary physical effort, and focused assessment on the product rather than on the decision-making process, whereas the commented machinima would capture everything.

Finally, machinima production techniques offer access to tools that allow rapid, rich media responses. If a set is already established the production of a visual response is within the grasp of both students and academics, and this can be useful in offering visual feedback, especially where digital media-enhanced pedagogies are already used. The Business tutor appreciated that student groups would respond differently to the machinima of the Managing Director's briefing and noted the potential to generate further machinima in response to their initial submissions.

\section{Creativity in teaching and learning}

All six participants readily engaged with the design methodology and enjoyed the opportunity to work creatively. They demonstrated familiarity with the grammar of film, quickly accepting suggestions, and proposing their own. They introduced visual techniques, such as mixing real and virtual footage. In the Education case study, for example, the value of a 
real-world audio track demonstrating classroom disruption mixed with IVW footage was seen as useful.

The case studies each highlight one of several ideas that were generated quickly. Often many and varied ideas were explored. The conversational approach, anchored to the design proforma, was effective in generating and refining ideas.

\section{The application of media intervention methodology}

Participants readily understood and valued the concept of media intervention, where digital media is used as a "catalyst for learning" (Psychology academic), though all thought in terms of series, or sets of machinima rather than individual objects. In Microbiology the academic believed machinima "interspersed in a lecture" would engage and interest students more than current methods and would be more "stimulating and exciting".

Classroom disruption is a difficult topic to address; techniques such as role play often fail to capture the chaos. The Education academic felt that media interventions depicting difficult situations could generate empathy and help students to predict such behaviour whilst on placement. They could serve as useful reference points when communicating their own placement experience to others and as discussion points in group decision-making. The lecturer, recognising the catalytic potential of media said, "You don't need to look for solutions necessarily within the media itself".

\section{Models for the generation of educational machinima}

None of the academics interviewed proposed student-produced machinima ideas without prompting. However, once the potential had been introduced, it generally found favour. This response from the Criminology academic was typical:

\footnotetext{
That's really challenging me now. Well it would be a good test of their learning. It would be a good learning experience, because I'm saying you need to get all those cues in. Well that would be a really, really hard thing for them to do. It would be something I'd have to think about. They'd need to show their learning in terms of, not the technical construction, but in terms of have they really understood what the role of the Crown Prosecution Service is. Well it wouldn't just be through having a Prosecutor and a pile of files there. It would be about showing that they'd made the decision about the evidential test and the public interest test, and that they showed their independence from the police, and they were thinking forward to how the court process would go. So yes, if they showed that in the machinima then I would say that's a demonstration of the conceptual knowledge I want them to have as Criminology students. Yes. Ooh, that's pushed me a bit!
}

Though the research was primarily interested in the generation of ideas, it was inevitable that the practicalities of production would be raised. None of the academics saw it as their role to construct the machinima themselves, leaving three options:

- a team of learning technologists;

- their own students; and

- technical students (e.g. from computing courses).

Several variations emerged for each of these. The basis for engaging students was particularly interesting, with options ranging from paid employment or CV recognition for the production of machinima products, through inter-disciplinary learning collaborations, to students capturing the process of their own learning in IVWs. In Microbiology, for example, 
it was suggested that the students could be the content experts briefing an authentic project for Visualisation students and that this would provide a rare opportunity for authentic interaction in the subject with students learning how to articulate ideas to laypeople.

The Psychology academic commented that for IVWs to become accessible to all students as production environments, they would first have to feel "ordinary":

I don't want my students to spend a fortnight trying to work out how to use the software and a day trying to put the psychology into it.

There was some concern that the process might become a distraction and be time consuming. Following a similar experience of working with student producers, one academic noted that the supervision role had been arduous. The Sport lecturer wondered whether all students would be comfortable operating in such environments, although reflected on other student-generated media assignments that had worked for him following half-hour induction sessions. He thought that a library of student-generated machinima could become useful over time.

Rapid student machinima production (i.e. simple action capture) offered opportunities for Education and Sport where machinima could drive class discussion. On several occasions it was noted that the design process (e.g. discussion, script-writing, planning), rather than the filming process itself, could provide great value for collaborative learning.

\section{Reusability}

Many of the respondents recognised that the reusability of the virtual film set itself was more useful to them than the resultant machinima. In the Sport case study, for example, there is no need for each student to build a gym and its various equipment; their task is to lay out and describe the use of the space. In the Microbiology example the lecturer explained:

Once you've produced a typical bacteria with its virulence factors ... you could cut and paste different virulence factors onto the basic organism, and make it slightly different.

Reusability may also be found by offering students machinima stems that they are tasked with completing by introducing variables (e.g. decisions, viewpoints) and conclusions. This approach arose in the Criminology, Sport, Psychology and Microbiology discussions.

In Sport and Microbiology it was suggested that students could contribute to the creation of commented machinima content libraries, adding a degree of authenticity to the assignment, which could be used by current and future students.

\section{Visualisation and simulation}

Virtual worlds are visually immersive environments capable of supporting independent and social exploration. Visualisation is a key aspect of all the cases designed in this machinima study: in offering multiple perspectives of an event; in making records of a plan; through observing artefacts and evidence in an environment; in representing and developing the characters of protagonists; and in representing concepts visually. In addition, machinima can support the visualisation of relationships, processes and activities, including those that are inaccessible to students in the real world.

The verisimilitude may be limited, for example in the unrealistic movement of avatars, but all participants still valued the opportunity to visually represent their ideas. In Microbiology 
the tutor explained, "Microscopes can only look at living organisms at a very limited magnification of little spots ... very two dimensional and not very interesting at that scale".

\section{Discussion}

At this early stage the results are encouraging, especially with respect to the attitude of those who took part. Participants demonstrated that they were able to think creatively and cinematically, visualising how one shot would follow another. The specification and storyboarding of ideas proved to be a valuable and enjoyable exercise. Participants were initially asked to develop one idea, though often many ideas were generated in the design conversations. Even once the topic had been chosen, all participants were keen to keep hold of related ideas, noting that once the set has been dressed more use should be made of it.

Discussion about simplified production and access initially suggested that educational machinima production may be within the grasp of academic producers, enabling end-user independence and flexibility, though this may be inhibited where ideas are dependent upon large casts of avatar operators. However, it is disconcerting to note that, even amongst the selected innovators, there was clearly a reticence to imagine themselves creating their own machinima, even where the benefits had been enthusiastically discussed. This may be because they have never considered themselves as media producers before. Nevertheless, it indicates that the perceived barriers to such useful technologies are still too high for most.

Inter-disciplinary production, drawing upon and developing different areas of student expertise, was an idea that emerged as a production solution, though again comes with risks and an organisational overhead.

$3 \mathrm{D}$ visualisation, even when captured in $2 \mathrm{D}$ digital films, is an attractive quality of machinima to some academics; finding different viewpoints for an event or experiencing microscopic phenomena in-the-round cannot be easily achieved by other means.

The name Second Life indicates the notion of abstracted life, but the abstraction of rendered life in IVWs requires an acceptable degree of verisimilitude and fidelity so that users can make sense of, and believe in, what is happening (Boyle 1997). On the other hand Aldrich $(2005,81)$ notes how "simulation elements selectively represent objects or situations", and perhaps this indicates how these IVW media objects should be understood too. This abstraction, and its capture in machinima, appear to be acceptable in the cases discussed here, but may compromise other applications.

The topic of machinima reusability resulted in the focus shifting from reusable films towards reusable film sets, scenery and props. By establishing such material collections in the in-world IVW libraries, the technical and administrative barriers can be lowered: series or sets of machinima in related and unrelated disciplines become much more likely if such objects are already available. This priming activity may involve buying in properties, expert technical contributions, or extra-curricular opportunities for students. Priming approaches such as these would also help to address perceptions of technical barriers and the need for academics or their students to find time to develop their set and object construction skills. The authors have subsequently developed some of the scenarios described here with a minimal budget for props. Where it has not been possible to make items, free objects have been found in the Second Life library, images have been uploaded as scenery textures, free items have been found elsewhere, and occasionally items have been purchased from in-world stores (e.g. a suit for the Managing Director in Case Study 3). Once acquired, such props have been re-used.

Reusability should be considered with any content production. Machinima are selfcontained, highly granular, digital videos and, technically, would appear to be highly reusable. 
Pedagogically their reusability may be limited by over-contextualisation, for example where content is targeted at a particular subject, educational level (Currier and Campbell 2002) or by particular cultural and pedagogical approaches. Designing reusability into any learning content can be difficult (Collis and Strijker 2004). Machinima objects enable students to view them more than once, store and share them, modify them, and access them on a range of devices. The idea of reusable machinima stems, requiring completion by students, may offer opportunities for constructionist pedagogies.

The machinima designs developed in this study were intended to be around three minutes long, recognising that high-impact objects are more likely to affect learning. Brief media objects can be valuable informing components in an active learning landscape, whilst longer videos require a different type of learner engagement.

Beyond the case studies discussed here, there remains potential for other applications. For example, none of the participants proposed the use of machinima as a medium for reflective digital storytelling (Jenkins and Lonsdale 2007), though the linear nature of film is suited to such student narratives. Machinima could be used to present a visual identity to a real-world voice, as in the hypothetical case of child testimony that would otherwise not be ethically acceptable.

\section{Conclusion}

The scenarios considered here suggest that IVW machinima can find value across the curriculum, with many of the benefits being widely applicable. The six themes discussed here are by no means exhaustive; for example, understandings about learning through a captured, abstracted environment could be developed. The idea of machinima media intervention was readily accepted, resonating with awareness of other methods of intervention to promote student-centred learning. This simple use of media indicates how machinima production may be technically feasible, though development models for educational machinima are still required and suggest the need for further research.

\section{References}

Academy of Machinima Arts \& Sciences website. 2005. The machinima faq. http://www.machinima. org/machinima-faq.html.

Aldrich, C. 2005. Learning by doing: A comprehensive guide to simulations, computer games, and pedagogy in e-learning and other educational experiences. San Francisco: Pfeiffer; Chichester: John Wiley.

Bardzell, J., S. Bardzell, C. Briggs, K. Makice, W. Ryan, and M. Weldon. 2006. Machinima prototyping: An approach to evaluation. Proceedings of the 4th Nordic Conference on HumanComputer Interaction: Changing Roles, vol. 189, 433-36, Oslo, Norway.

Bradley, S., A. Middleton, and N. Nunnington. 2006. Media interventions: Designing video and audio to stimulate learning activity. Paper presented at DIVERSE (Developing Innovative Video Resources for Students Everywhere) Conference: Enriching e-learning using video and multimedia (both face-to-face and at a distance), Glasgow.

Bramhall, M., K. Radley, and J. Metcalf. 2008. Users as producers: Students using video to develop learner autonomy. Proceedings of Engineering Education 2008, international conference on innovation, good practice and research in education, 14-16 July 2008, at Loughborough University, UK.

Burbules, N. 1999. Technology in education: Who, where, when, what \& why? International Journal of Educational Technology 1, no. 1. http://www.ed.uiuc.edu/ijet/v1n1/v1n1 feature.html

Call, E. 2005. Making machinima in Second Life. http://static.secondlife.com/_files/making_ machinima.pdf

Carr, D. 2007. Machinima and education. http://www.futurelab.org.uk/resources/publications_ reports_articles/web_articles/Web_Article794. 
Collis, B., and J. Moonen. 2002. Flexible learning in a digital world: Experiences and expectations. London: Kogan Page.

Collis, B., and A. Strijker. 2004. Technology and human issues in reusing learning objects. Journal of Interactive Media in Education 4, Special Issue on the Educational Semantic Web. http:// www-jime.open.ac.uk/2004/4/collis-2004-4-disc-t.html.

Currier, S., and L. Campbell, L. 2002. Evaluating learning resources for reusability: The DNER \& Learning Objects study, in Winds of Changing in the Sea of Learning, Proceedings of the 19 th Annual Conference of the Australian Society for Computers in Tertiary Education (ASCILITE), Auckland, New Zealand, 8-11 December 2002, ed. Andy Williamson, Cathy Gunn, Alison Young and Tony Clear. Auckland, New Zealand: UNITEC Institute of Technology.

Czarnecki, K. 2007. Library services on the teen grid. In Proceedings, Second Life Education Workshop 2007, Part of the Second Life Community Convention, at the Chicago Hilton, August 24-26, ed. D. Livingstone, and J. Kemp. http://www.simteach.com/slccedu07 proceedings.pdf.

Daly-Swanson, B. 2007. Second Life machinima for libraries: The intersection of instruction, outreach and marketing in a virtual world. Paper presented at the World Library and Information Congress, 73rd IFLA General Conference and Council, August 19-23, in Durban, South Africa. http://www.ifla.org/IV/ifla73/papers/133-DalySwanson-en.pdf.

de Freitas, S. 2006. Using games and simulations for supporting learning. Learning, Media and Technology 31, no. 4: 343-58.

Dickey, M. 2005. Three-dimensional virtual worlds and distance learning: Two case studies of Active Worlds as a medium for distance education. British Journal of Educational Technology 36, no. 3: 439-51.

Horizon Project. 2008. The Horizon report 2008 edition - A collaboration between The New Media Consortium and the EDUCAUSE Learning Initiative. http://www.nmc.org/pdf/2008-HorizonReport.pdf.

Hung, V.H.K., M. Keppell, and M.S.Y. Jong. 2004. Learners as producers: Using project based learning to enhance meaningful learning through digital video production. In Beyond the comfort zone: Proceedings of the 21 st ASCILITE Conference, December 5-8, in Perth, ed. R. Atkinson, C. McBeath, D. Jonas-Dwyer, and R. Phillips, 428-36. http://www.ascilite.org.au/conferences/ perth04/procs/hung.html.

Jenkins, M., and J. Lonsdale. 2007. Evaluating the effectiveness of digital storytelling for student reflection. In ICT: Providing choices for learners and learning. Proceedings ASCILITE Singapore 2007. http://www.ascilite.org.au/conferences/singapore07/procs/jenkins.pdf.

Joseph, B. 2007. Global Kids, Inc.'s best practices in using virtual worlds for education. In Proceedings, Second Life Education Workshop 2007, Part of the Second Life Community Convention, at the Chicago Hilton, August 24-26, ed. D. Livingstone, and J. Kemp. http://www.simteach.com/ slccedu07proceedings.pdf.

Kafai, Y.B. 1996. Learning design by making games: Children's development of design strategies in the creation of a complex computational artifact. In Constructionism in practice: Designing, thinking, and learning in a digital world, ed. Y.B. Kafai, and M. Resnick, 71-96. Mahwah, NJ: Lawrence Erlbaum Associates.

Kirriemuir, J. 2007. An update of the July 2007 "snapshot" of UK higher and further education developments in Second Life. http://www.eduserv.org.uk/foundation/sl/uksnapshot092007.

Laurillard, D. 2002. Rethinking university teaching: A conversational framework for the effective use of learning technologies, 2nd ed. London: RoutledgeFalmer.

Littleton, F., and S. Bayne. 2008. Virtual worlds in education. The Higher Education Academy Subject Centre for Education, Newsletter No. 10, Spring 2008. http://escalate.ac.uk/4453

Lombardi, M.M. 2007. Authentic learning for the 21st century: An overview. ELI paper 1, Educause, May 2007. http://www.educause.edu/ir/library/pdf/ELI3009.pdf.

Lowood, H. 2006. High-performance play: The making of machinima. Journal of Media Practice 1: $25-42$.

Middleton, A. 2008. Audio feedback: Timely media interventions. In Proceedings of The Third International Blended Learning Conference, 'Enhancing the Student Experience', June 18-19, at the University of Hertfordshire, UK, 15-27.

Nitsche, M. 2005. Film live: An excursion into machinima. In Developing interactive narrative content: Sagas_sagasnet_reader, ed. B. Bushoff, 210-43. Munich: High Text Verlag. 
Papert, S. 1986. Constructionism: A new opportunity for elementary science education. A proposal to the National Science Foundation, Cambridge, MA, Massachusetts Institute of Technology, Media Laboratory, Epistemology and Learning Group.

Roberts, C. 2008. Implementing educational technology in higher education - A strategic approach. The Journal of Educators Online 5, no. 1. http://www.thejeo.com/Archives/Volume5Number1/ RobertsPaper.pdf

Shephard, K. 2003. Questioning, promoting and evaluating the use of streaming video to support student learning. British Journal of Educational Technology 34, no. 3: 295-308.

Yoon, S.-W, and D.H. Lim. 2007. Strategic blending: A conceptual framework to improve learning and performance. International Journal on E-Learning 6, no. 3, 475-90. 


\section{Appendix 1 - Machinima used in the research process}

\section{A Whale of a Tale}

http://www.youtube.com/watch?v=q_54JGOSE0g\&feature=user

A short film about a fishing trip, used to illustrate the potential of Second Life for creating machinima.

\section{What is Machinima?}

http://www.youtube.com/watch?v=dPLzKur06Vo\&feature=related

A movie where an avatar explains the concept of machinima. Used to introduce participants to machinima.

\section{Second Life: Get One}

http://www.youtube.com/watch?v=xxj8RTW4ev4\&NR=1

A promotional movie about Second Life. Used to introduce participants to Second Life.

\section{Architecture on the Double}

http://www.youtube.com/watch?v=R7bXu2ozXo0\&feature=user

A film that shows the construction of a house by a group of avatars. Used to show how Second Life can be used collaboratively.

\section{What is a Prim? - Second Life Video TuTORial}

http://www.youtube.com/watch?v=8tlcXwR-A2s

A quick description of what prims are, used to show participants the basic construction components of Second Life.

\section{Fruit Fly Genetics Experiment}

http://www.youtube.com/watch?v=08f1rG-D1uA

A simulation of a fruit fly genetics experiment, to illustrate a lab setting, and the use of an HUD (Head Up Display) to guide users through the experiment.

\section{Heart Murmur Sim}

http://www.youtube.com/watch?v=xJY2Iwbzop4

A short film that shows a simulation of various heart conditions. This demonstration shows how students can interrogate a virtual world audio enhanced simulation.

\section{Second Health: Emergency and Specialist Care}

http://www.youtube.com/watch?v=Mp8IyXZAv-U\&feature=related

A machinima explaining how paramedics can respond to someone having a heart attack. Mixing 3D virtual world footage with other media including graphics and video. The machinima provides an overview of services and processes to the layperson. 